ISSN 1392-3196 / e-ISSN 2335-8947

Zemdirbyste-Agriculture, vol. 101, No. 1 (2014), p. 3-10

DOI 10.13080/z-a.2014.101.001

\title{
Potassium leaching from Endocalcari-Endohypogleyic Cambisol as influenced by precipitation rate and crop management
}

\author{
Angelija BUČIENĖ ${ }^{1}$, Šarūnas ANTANAITIS ${ }^{2}$, Alvyra ŠLEPETIENE ${ }^{2}$, Dana ŠIMANSKAITÉ ${ }^{2}$ \\ Vytas MAŠAUSKAS ${ }^{2}$, Martynas BUČAS ${ }^{1}$ \\ ${ }^{1}$ Klaipèda University \\ Minijos 153, Klaipeda, Lithuania \\ E-mail: angelija.buciene@ku.lt \\ ${ }^{2}$ Institute of Agriculture, Lithuanian Research Centre for Agriculture and Forestry \\ Instituto 1, Akademija, Kedainiai distr., Lithuania
}

\begin{abstract}
The aim of this research was to compare a few crop management systems in respect of potassium leaching in order to reduce the leaching losses. Research was carried out on an Endocalcari-Endohypogleyic Cambisol (CMg- $n$-wcan) at the experimental site of Lithuanian Institute of Agriculture (currently - Institute of Agriculture, Lithuanian Research Centre for Agriculture and Forestry). The focus was on the search for factors responsible for leaching, including precipitation amount and rate, and selected soil properties.

The highest potassium cation $\left(\mathrm{K}^{+}\right)$leaching with drainage runoff $3.8 \mathrm{~kg} \mathrm{ha}^{-1}$ year ${ }^{-1}$ was determined in the conventional system with high $\mathrm{K}$ inorganic fertilization level as compared with $1.9 \mathrm{~kg} \mathrm{ha}^{-1} \mathrm{year}^{-1}$ in the treatment with zero fertilization (reference) during the first research period in 1995-1999. However, later, after a few changes in experimental design and under the drier conditions, leaching of $\mathrm{K}^{+}$was low and similar in all crop management treatments on the arable plots (approx. $1.6 \mathrm{~kg} \mathrm{ha}^{-1} \mathrm{year}^{-1}$ ). The rate of $\mathrm{K}$ and $\mathrm{N}$ fertilizers positively influenced the leaching of $\mathrm{K}^{+}$only during the normal and wet years with precipitation rate $>450-600 \mathrm{~mm}$. The content of soil aggregates $<0.25 \mathrm{~mm}$ in topsoil positively correlated with $\mathrm{K}^{+}$leaching losses during the first research period $(P<0.01)$. During the whole research period the precipitation rate was the factor from the main effects, which explained $64 \%$ of the $\mathrm{K}^{+}$leaching variance. The final model explained $76 \%$ of $\mathrm{K}^{+}$leaching variance for all data and $65 \pm 16 \%$ on cross-validation data, showing relatively high and stable accuracy of predictions. Among the variables, the interaction of precipitation rate and content of humus, the interaction between the precipitation rate and content of soil aggregates $<0.25 \mathrm{~mm}$ were the most important, each explaining more than $60 \%$ of the variance of $\mathrm{K}^{+}$leaching losses.
\end{abstract}

Key words: crop management systems, humus content, leaching, potassium cation $\left(\mathrm{K}^{+}\right)$, precipitation.

\section{Introduction}

The potassium $(\mathrm{K})$ is an important element in agriculture particularly in grass-enriched cropping systems. The efficiency of organic manures as a $\mathrm{K}$ sources depends largely on the initial content of plant available $\mathrm{K}$ in soil, soil texture and climate patterns (Krauss, 2000; Kayser, Isselstein, 2005; Alfaro et al., 2006). However, there are still many unclear moments in the migration of $\mathrm{K}^{+}$within soil-plant system, particularly because of unquantified uptake of $\mathrm{K}$ from the subsoil, weathering intensity, poorly quantified $\mathrm{K}$ leaching particularly under continuous organic mixed arable systems (Gosling, Shepherd, 2005; Singh, Goulding, 2008; Öborn et al., 2008). The data obtained from the experiments conducted on a sandy loam Cambisol confirm that an average annual $\mathrm{K}^{+}$leaching rate was 9.4-10.0 kg ha- in fertilised soil and $7.5 \mathrm{~kg} \mathrm{ha}^{-1}$ in not fertilised soil (Mašauskas, Mašauskienè, 2010). Potassium concentration and leaching rate depended on the soil type, which was shown in long-term lysimeter experiments carried out in Lithuania (Tyla et al., 1997).
The goal of sustainable crop management systems is to achieve the optimal level of nutrient balance in order to maintain the high yield level with the minimised losses from the agroecosystem to other ecosystems (Tivy, 1987). The aim of this research was to compare a few crop management systems in respect of the major nutrient flow in order to reveal the most problematic points and to reduce the losses in the plant-soil-water system. With this material we focused on the $\mathrm{K}$ flow and leaching with drainage runoff as well as the factors responsible for it under the different crop management systems and year climatic conditions, reflected mainly by the precipitation amount and rate.

\section{Materials and methods}

Two high-input - conventional and integrated, two low-input organic, one reference-zero input systems, and one long-term pasture were studied and compared in 1995-1999 and after a few changes in management 
continued to be studied in 2001-2007. The experiment was established on an Endocalcari-Endohypogleyic Cambisol (CMg-n-w-can) composed of sandy-loam and light loam in the experimental site of Institute of Agriculture, Lithuanian Research Centre for Agriculture and Forestry located in Akademija, Kedainiai district. The site was made of 11 drainage plots, ranging in size from 0.34 to 0.38 ha each. Field drains were placed mainly at a depth of around $1 \mathrm{~m}$. Drainage water flow was registered continuously by water-stage recorders. The sampling and analyses of chemical composition of drainage runoff water were conducted every second week or monthly during the discharge periods of the whole experimental time. The data on quantity of wet deposits were taken from Dotnuva Meteorological Station, located in Akademija too. Samples of wet atmospheric deposits were collected using a precipitation receiver at $0.5 \mathrm{~m}$ height connected with a 3 -litre bottle and fixed on the meteorological ground. The chemical composition of wet deposits was determined monthly or more often (depending on the precipitation rate) during the first research period at the Chemical Research Laboratory of Institute of Agriculture, Lithuanian Research Centre for Agriculture and Forestry located in Akademija. Potassium (K) content in both drainage water and wet deposits was determined by flame photometry.

The field crop rotation for the first crop management research stage consisted of winter wheat, potato, spring barley with undersown ley and ley of - first year of use and was established in the drainage plots from D-1 to D-10. Every year, one crop in the rotation was grown. The long-term pasture (LTP) (drainage plot D-11) had been used for more than 50 years without re-seeding. Poa pratensis, Phleum, Agropyron repens, Alopecurus pratensis, Dactylis glomerata dominated the sward, legumes were very few ( $<1 \%$ of plant composition).

In the conventional (CON) system, the crops were fertilized with inorganic fertilizers at recommended rates for obtaining the maximum yield, and various pesticides were applied. In the integrated (INT) system, both the farmyard manure (50 $\mathrm{t} \mathrm{ha}^{-1}$ FYM before potato sowing) and inorganic fertilizers were used at recommended rates and pesticides were applied in the case of necessity only during the first rotation. In the first organic (ORG1) system, $25 \mathrm{t} \mathrm{ha}^{-1}$ FYM was ploughed down before winter wheat sowing and $3 \mathrm{t} \mathrm{ha}^{-1}$ dry matter of winter oilseed rape mass as green manure was incorporated before potato planting in spring. In the second organic (ORG2) system, $35 \mathrm{tha}^{-1}$ compost of sewage sludge from Akademija wastewater treatment plant and winter wheat straw were applied instead of FYM. In general, CON and INT treatments may be considered as high input systems and both organic treatments as low input systems. In the LTP, it was estimated that one cow during the grazing season leaves in the pasture with excrements $12 \mathrm{~kg} \mathrm{~N}$, $3.8 \mathrm{~kg} \mathrm{P}_{2} \mathrm{O}_{5}$ and $12 \mathrm{~kg} \mathrm{~K}_{2} \mathrm{O}$ on the average. In 1995-1999 period, four cows per ha of pasture were grazed. In spring, the pasture was fertilized with $90 \mathrm{~kg} \mathrm{ha}^{-1} \mathrm{~N}, 24 \mathrm{~kg} \mathrm{ha}^{-1} \mathrm{P}$ and $50 \mathrm{~kg} \mathrm{ha}^{-1} \mathrm{~K}$ (as ammonium nitrate, superphosphate and potassium chloride).

During the second research period, 2001-2007, the LTP treatment continued to be the same, except for the number of cows per ha of pasture, which was reduced from 4 to 2, based on the European Union Nitrate directive. In other treatments - a four-course-crop rotation was chosen: winter wheat, spring rapeseed, spring barley with undersown clover and clover of first year of use. The ORG2 treatment was not continued in 2001-2007. This rotation was extended in the space: four crops were grown in each treatment every year. In all the treatments in 2001-2007, unlike in the first experiment, winter wheat and rapeseed straw after harvesting was chopped, spread and incorporated in the soil in the autumn. Spring barley straw was removed from the field. FYM was not applied, and the difference between CON and INT treatments was in the rate of mineral fertilizers: in the $\mathrm{CON}$ treatment the rate was targeted to obtain the maximum yield, and in the INT - to cover the medium crop requirements for the main nutrients. In the ORG1 treatment, the need for nitrogen $(\mathrm{N})$ was covered by biological $\mathrm{N}$ of clover, which was undersown in winter wheat and in barley in spring. Potassium need was covered by potassium sulphate and potassium chloride.

Crop yield was harvested from $36-44 \mathrm{~m}^{2}$ plots in four replicates. The samples of grain, straw, potato tubers, ley, rapeseed, clover biomass were analysed for $\mathrm{K}$ content by a flame photometry method. Plant K uptake was calculated multiplying yield (grain and straw weights at $85 \%$, rapeseed at $91 \%$, potato tuber and ley weights at $100 \%$ dry matter) by percentage of $\mathrm{K}$ in the plant material. Soil samples for chemical analyses were collected every year after harvesting (making 6-8 bore holes by the field diagonal in each plot of the four replicates) from both topsoil and subsoil. Plant available $\mathrm{K}_{2} \mathrm{O}$ was determined by the A-L method according to Egnér et al. (1960). The humus content of soil was determined by the Tyurin method. Soil macrostructure composition was determined by the Savinov method (Vadiunina, Korchiagina, 1986) in 1996 and again in 1999. We measured the percentage of aggregates of $<0.25,0.25-5,>5(5-7,7-10,>10) \mathrm{mm}$ by dry sieving bulked samples of topsoil in three replicates. The hydrological years were contrasting: 1995-1996, 2001-2002, 2002-2003 and 2005-2006 distinguished by low (<450 mm), 1996-1997, 2003-2004, 2004-2005- by medium (450-600 mm), 1997-1998, 1998-1999, 2006-2007 - by high (>600 mm) precipitation amount. The drainage runoff made from $16-20$ to $52-66 \%$ of the annual precipitation amount. Thus according to the precipitation amount and discharge magnitude, the years were grouped into wet, dry and normal.

Differences in $\mathrm{K}^{+}$leaching during two research periods between crop management treatments were tested using ANOVA (SPSS for Windows 8.0) procedure for $\mathrm{LSD}_{05}$. Regression-correlation analysis was performed in order to determine the relations among soil properties, fertilizer and precipitation rate, runoff and $\mathrm{K}^{+}$leaching results. The importance of four factors (precipitation rate, $\mathrm{K}_{2} \mathrm{O}-\mathrm{AL}$, content of soil aggregates $<0.25 \mathrm{~mm}$ and humus content in the topsoil and their interaction effects on the $\mathrm{K}^{+}$leaching was assessed by generalized additive models (mgcv package for $R$ version 2.15.1), due to non-linear empirical relationships (Zuur et al., 2007) between some factors. This analysis was performed for all treatments excluding LTP, where data was 1000 times randomly split to train data $(75 \%)$ for the calibration and internal validation of the model, and test data $(25 \%)$ for validation of predictive performance of the model. The most appropriate non-linear regression model was selected based on penalized regression splines with default gamma-values and maximum five degrees of 
freedom in order to maintain interpretable models (Wood, Augustin, 2002). The relative importance of factors and interactions was estimated using $F$ values.

\section{Results and discussion}

Soil background, precipitation, runoff and $K$ load with wet atmosphere deposits. In Lithuania, the soils poor in available $\mathrm{K}$ (less $100 \mathrm{mg} \mathrm{kg}{ }^{-1} \mathrm{~K}_{2} \mathrm{O}$ determined by A-L method) make up about $17.4 \%$ (Mažvila et al., 2004). The research site of the Institute of Agriculture, Lithuanian Research Centre for Agriculture and Forestry represents the typical soils of Central Lithuania formed from the ground moraine drifts. The parent rocks are calcareous, the carbonates accumulate mostly in the upper layer with maximum in $40-60 \mathrm{~cm}$ depth. The relief of the site is a little sloping, the evaporation is higher and the precipitation level is lower than the average in Lithuania (Agrochemical properties..., 1998; Mašauskas, Mašauskienè, 2006). The EndocalcariEndohypogleyic Cambisol (CMg- $n-w-c a n)$ dominated in the site. According to the content of plant available $\mathrm{K}_{2} \mathrm{O}$, the plots in the experimental site distinguished by lower values than Lithuania's average in the plots with arable crop rotation, but in the topsoil of LTP treatment it was almost twice as high. The texture of topsoil in all drainage plots was sandy-loam or light loam, in subsoil it was varying from sandy-loam to clay-loam (Table 1).

Table 1. Average values of selected soil properties in different layers before the trial establishment, 1991-1995

\begin{tabular}{ccccccc}
\hline $\begin{array}{c}\text { Depth } \\
\mathrm{cm}\end{array}$ & $\begin{array}{c}\mathrm{K}_{2} \mathrm{O}(\mathrm{A}-\mathrm{L}) \\
\mathrm{mg} \mathrm{kg}^{-1}\end{array}$ & $\begin{array}{c}\text { Humus } \\
\%\end{array}$ & $\begin{array}{c}\text { Clay } \\
\%\end{array}$ & $\begin{array}{c}\text { Silt } \\
\%\end{array}$ & $\begin{array}{c}\text { Sand } \\
\%\end{array}$ & $\begin{array}{c}\text { Soil aggregates } \\
(<0.25 \mathrm{~mm}) \\
\%^{*}\end{array}$ \\
\hline \multicolumn{7}{c}{ Average data from D1-D10 drainage plots (with field crop rotation) } \\
\hline $0-20$ & $77.4 \pm 2.0$ & $2.68 \pm 0.12$ & $11.6 \pm 1.2$ & $34.0 \pm 2.7$ & $54.4 \pm 2.8$ & $10.0 \pm 4.7$ \\
$20-40$ & $83.4 \pm 3.2$ & $1.66 \pm 0.22$ & $18.2 \pm 2.5$ & $30.6 \pm 3.5$ & $51.0 \pm 3.3$ & nd \\
$40-60$ & $79.0 \pm 2.9$ & $0.72 \pm 0.15$ & $17.2 \pm 2.3$ & $29.0 \pm 2.8$ & $53.7 \pm 3.8$ & nd \\
\hline $0-20$ & $152.0 \pm 38.1$ & $4.10 \pm 0.21$ & $12.0 \pm 1.0$ & $36.5 \pm 1.5$ & $51.5 \pm 0.5$ & $7.0 \pm 0.4$ \\
$20-40$ & $82.0 \pm 12.7$ & $4.01 \pm 0.05$ & $14.5 \pm 0.5$ & $34.5 \pm 2.5$ & $53.5 \pm 0.5$ & nd \\
$40-60$ & $94.0 \pm 12.7$ & $1.16 \pm 0.36$ & $23.5 \pm 9.5$ & $33.0 \pm 4.0$ & $35.0 \pm 5.0$ & nd \\
\hline
\end{tabular}

nd - not determined, * - determined in 1996

The humus content in topsoil ranged from $2.0 \%$ to $4.0 \%$ depending on the plot. The topsoil structural composition varied in the space as well: the content of soil aggregates $<0.25 \mathrm{~mm}$ was higher in the arable plots (D-1-D-10) as compared to the pasture (D-11). Monthly values of precipitation amount are presented in Figure 1.

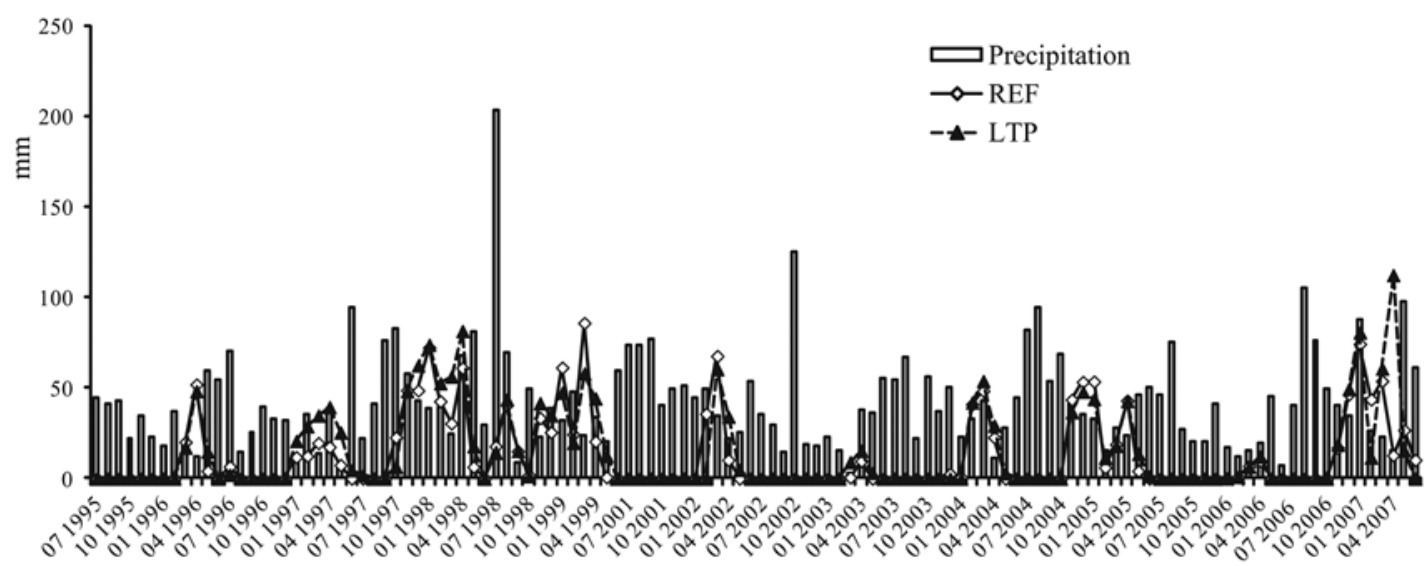

Figure 1. Monthly precipitation rate from Dotnuva Meteorological Station in 1995-2007 and runoff in the reference (REF) and long-term pasture (LTP) treatments during the same research period

The monthly drainage runoff data of two crop management treatments - reference and long term pasture are presented there too. The figure shows the higher precipitation and consequently runoff values in the first research period and by the end of the second one, while during the rest of the period the drier years prevailed. The runoff magnitude in the arable plots on the average was somehow lower, than in the LTP. During the first research period (1995-1999), available $\mathrm{K}_{2} \mathrm{O}-\mathrm{AL}$ in the topsoil increased significantly in $\mathrm{CON}$ and REF treatments, and by a hefty $40.7 \pm 1 \mathrm{mg} \mathrm{kg}$ in the INT treatment, but did not change in the other two treatments on arable plots. Differently, in the LTP treatment it decreased significantly; however, in the subsoil of all treatments it remained unchanged. The humus content of the topsoil increased significantly in the INT, and of the subsoil in the INT and ORG1, while in the other treatments the changes were not significant (Bučienè et al., 2003). During the second research period (2001-2007), available $\mathrm{K}_{2} \mathrm{O}-\mathrm{AL}$ increased significantly in the topsoil of LTP treatment, while it did not change in other treatments (Table 2). 
Table 2. Content of available $\mathrm{K}_{2} \mathrm{O}-\mathrm{AL}$, humus and soil aggregates $<0.25 \mathrm{~mm}$ of topsoil in the different treatments in 1999 and 2001-2007

\begin{tabular}{cccccc}
\hline \multirow{2}{*}{ Treatment } & \multicolumn{2}{c}{$\begin{array}{c}\text { Available } \\
\mathrm{K}_{2} \mathrm{O}-\mathrm{AL} \\
\mathrm{mg} \mathrm{kg}\end{array}$} & \multicolumn{2}{c}{$\begin{array}{c}\text { Humus } \\
\%\end{array}$} & $\begin{array}{c}\text { Soil aggregates } \\
<0.25 \mathrm{~mm} \\
\%\end{array}$ \\
\cline { 2 - 6 } & 2001 & 2007 & 2001 & 2007 & 1999 \\
\hline CON & 110 & 125 & 2.01 & 2.55 & $7.0 \pm 1.0$ \\
INT & 111 & 115 & 2.00 & 2.50 & $5.9 \pm 0.6$ \\
ORG1 & 122 & 133 & 1.98 & 2.66 & $4.1 \pm 0.2$ \\
REF & 99 & 96 & 1.96 & 2.69 & $3.8 \pm 0.2$ \\
LTP & 87 & $121 *$ & 3.65 & 3.96 & $6.6 \pm 0.8$ \\
\hline
\end{tabular}

CON - conventional, INT - integrated, ORG1 - organic first crop management system, REF - reference, LTP - long term pasture; $*-\mathrm{t}_{\text {act }}>\mathrm{t}_{05}$
The changes of other soil properties during the second research period were statistically insignificant in all the treatments. From 1988 to 2000 the samples of wet atmospheric deposits were analysed in the Chemical Research Laboratory of Lithuanian Institute of Agriculture. The $\mathrm{K}$ concentration and amount in wet atmospheric deposits was fluctuating from year to year, and the average amount of deposited $\mathrm{K}^{+}$during that period made up about $4.3 \mathrm{~kg} \mathrm{ha}^{-1} \mathrm{yr}^{-1}$ (Bučienè et al., 2003).

Fertilization, yield and $K$ uptake. During the first research period, $\mathrm{K}$ content in fertilizers in the high input treatments was about twice as high in the low input treatments, whereas during the second one the difference between those treatments was less expressed. The REF treatment during the second research period also received some $\mathrm{K}$ input due to the winter wheat and rapeseed straw incorporation (Table 3 ).

Table 3. Annual mean potassium $(\mathrm{K})$ fertilization rate $\left(\mathrm{kg} \mathrm{ha}^{-1} \mathrm{yr}^{-1}\right)$, crop yield $\left(\mathrm{tha}^{-1}\right)$ and $\mathrm{K}$ uptake $\left(\mathrm{kg} \mathrm{ha}^{-1} \mathrm{yr}^{-1}\right)$ from the different crop management treatments during 1995-1999 and 2001-2007 research periods

\begin{tabular}{|c|c|c|c|c|c|c|}
\hline & $\mathrm{CON}$ & INT & ORG1 & ORG2 & REF & LTP \\
\hline \multicolumn{7}{|c|}{$1995-1999$} \\
\hline Fertilizer K & $103^{\mathrm{a}}$ & $\begin{array}{c}116^{\mathrm{c}} \\
\left(68.1^{\mathrm{a}}+47.9^{\mathrm{b}}\right)\end{array}$ & $47.3^{b}$ & $38.7^{\mathrm{b}}$ & 0 & $\begin{array}{c}90^{\mathrm{c}} \\
\left(50^{\mathrm{a}}+40^{\mathrm{b}}\right)\end{array}$ \\
\hline Winter wheat grain ${ }^{\mathrm{d}}$ & $6.9 \pm 0.19$ & $5.4 \pm 0.19$ & $3.6 \pm 0.16$ & $3.4 \pm 0.11$ & $3.8 \pm 0.20$ & $5.0^{\mathrm{g}} \pm 0.37$ \\
\hline Potato $^{\mathrm{e}}$ & $25.6 \pm 0.93$ & $25.2 \pm 0.91$ & $16.3 \pm 0.94$ & $11.9 \pm 0.46$ & $11.1 \pm 0.35$ & \\
\hline Barley grain ${ }^{\mathrm{d}}$ & $4.8 \pm 0.11$ & $5.0 \pm 0.16$ & $3.5 \pm 0.11$ & $6.0 \pm 0.09$ & $2.5 \pm 0.14$ & \\
\hline Ley $^{\mathrm{f}}$ & $5.1 \pm 0.15$ & $4.4 \pm 0.25$ & $9.2 \pm 0.27$ & $4.6 \pm 0.18$ & $7.8 \pm 0.39$ & \\
\hline Uptake K & 93 & 88 & 79 & 58 & 46 & 144 \\
\hline \multicolumn{7}{|c|}{ 2001-2007 } \\
\hline Fertilizer K & $\begin{array}{c}139.6^{\mathrm{c}} \\
\left(89.2^{\mathrm{a}}+50.4^{\mathrm{b}}\right)\end{array}$ & $\begin{array}{c}99.4^{\mathrm{c}} \\
\left(56^{\mathrm{a}}+43.4^{\mathrm{b}}\right)\end{array}$ & $\begin{array}{c}93.8^{\mathrm{c}} \\
\left(47^{\mathrm{a}}+46.8^{\mathrm{b}}\right)\end{array}$ & - & $38^{\mathrm{b}}$ & $\begin{array}{c}70^{c} \\
\left(50^{a}+20^{b}\right)\end{array}$ \\
\hline Winter wheat grain ${ }^{\mathrm{d}}$ & $6.6 \pm 0.94$ & $6.0 \pm 0.87$ & $5.9 \pm 0.97$ & - & $6.1 \pm 1.04$ & $5.2^{\mathrm{h}} \pm 0.20$ \\
\hline Spring rapeseed ${ }^{\mathrm{i}}$ & $2.06 \pm 0.39$ & $1.92 \pm 0.36$ & $1.74 \pm 0.38$ & - & $1.57 \pm 0.18$ & \\
\hline Barley grain ${ }^{\mathrm{d}}$ & $5.5 \pm 1.07$ & $5.1 \pm 0.88$ & $4.2 \pm 0.51$ & - & $4.8 \pm 0.51$ & \\
\hline Ley $(\text { clover })^{\mathrm{f}}$ & $1.9 \pm 1.43$ & $2.4 \pm 0.85$ & $2.8 \pm 0.84$ & - & $2.4 \pm 0.59$ & \\
\hline Uptake K & 95 & 73 & 71 & - & 65 & 149 \\
\hline
\end{tabular}

${ }^{\mathrm{a}}$ - in mineral fertilizers, ${ }^{\mathrm{b}}-$ in organic fertilizers, ${ }^{\mathrm{c}}-$ in both organic and mineral fertilizers, ${ }^{\mathrm{d}}-85 \%$ of dry matter, ${ }^{\mathrm{e}}-$ fresh tubers,

${ }^{\mathrm{f}}-$ ley $100 \%$ dry matter, ${ }^{\mathrm{g}}-4$ year average ley $100 \%$ dry matter, ${ }^{\mathrm{h}}-3$ years average ley $100 \%$ dry matter, ${ }^{\mathrm{i}}-91 \%$ of dry matter

The yield of winter wheat grain in the CON treatment was by $22 \%$ higher on the average than in the INT, and by $45-51 \%$ higher than in ORG and REF treatments in 1995-1999. Maximum potato yield was obtained in the CON treatment, a little lower in the INT, but by $36-57 \%$ lower in other treatments. Barley yielded most in ORG2, and the first year ley in the ORG1. The largest $\mathrm{K}$ uptake was registered in the LTP treatment. The yield of dry matter in the LTP differed 2-3 times between years depending mostly on the year hydrothermal conditions. During the second research period, winter wheat, spring barley and ley yield in different treatments did not differ significantly, only the rapeseed yield was by $31 \%$ higher in the CON as compared with REF treatment. The $\mathrm{K}$ uptake in the INT and ORG1 treatments was very similar to that in the 1995-1999 period.

Dependence of $K$ concentration in drainage runoff and leaching upon different factors. The seasonal variation in the runoff magnitude was taking place: the highest runoff occurred during early spring months March and April; however, during three hydrological years out of ten it was also high from NovemberDecember till May. The highest $\mathrm{K}$ concentration during the first research period was in the INT and CON, the lowest in the REF and LTP treatments (Fig. 2 a). During the second research period, the highest $\mathrm{K}$ concentration was in the CON, INT and ORG1 treatments, and the lowest remained again in the LTP (Fig. 2 b).

Calculations revealed, that $\mathrm{K}^{+}$leaching during 1995-1999 was as follows: CON > INT > LTP > ORG1 > ORG2 > REF; however, the significantly higher leaching of $\mathrm{K}^{+}$was determined only in the CON treatment as compared with the REF (Fig. 2). The second research period was running under the drier weather conditions, thus the leaching losses of all nutrients (including $\mathrm{N}$ and $\mathrm{P}$ ) were 2-3 times lower than in the years with normal precipitation/discharge magnitudes, and similar in all the treatments. $\mathrm{K}^{+}$leaching during the second research period was slightly higher in the CON treatment, and decreased as follows: CON $>$ INT $>$ REF $>$ ORG1 > LTP. In general, the K drainage losses by magnitude depended more on the year climatic conditions than on crop management (Table 4).

$\mathrm{K}^{+}$leaching losses were 3-5 times higher in wet hydrological years as compared with normal, and conversely, during the dry conditions, leaching was negligible. The correlation between leaching of $\mathrm{K}^{+}$and the rate of $\mathrm{K}(r=0.87, P<0.05)$ and $\mathrm{N}$ fertilizers $(r=0.75$, $P=0.05)$ was found only during 1995-1999, whereas no correlation was determined in the drier 2001-2007 period ( $r=0.46$ and $r=0.34$, respectively; $P>0.05$ ) (Fig. $3 \mathrm{a}, \mathrm{b}$ ). As to the soil properties, close correlation was determined between leaching of $\mathrm{K}^{+}$and content of 


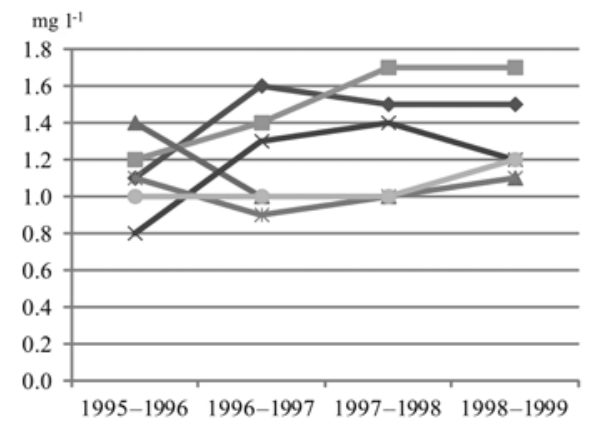

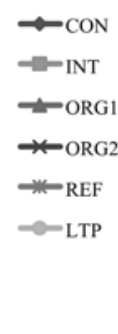

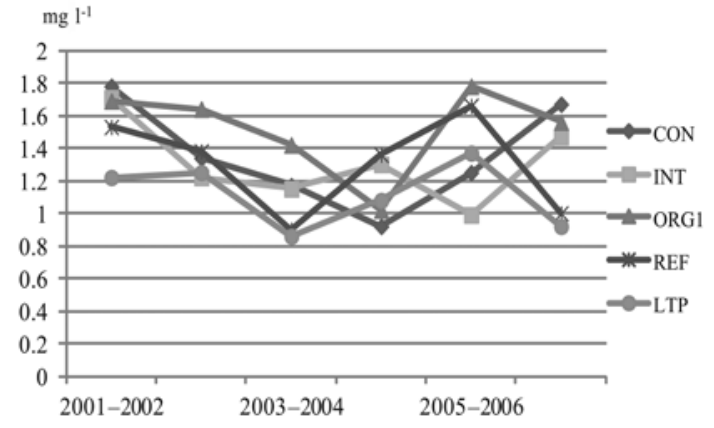

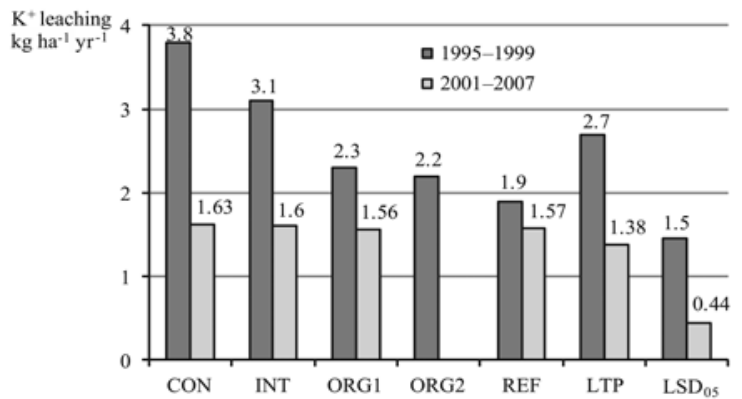

Explanations of treatments under Table 2; ORG2 - organic second

Figure 2. Yearly average potassium $(\mathrm{K})$ concentration in drainage runoff $\left(\mathrm{a}\right.$ and $\mathrm{b}$ ) and leached $\mathrm{K}^{+}$amount $(\mathrm{c})$ from the different crop management treatments in two research periods 1995-1999 and 2001-2007

Table 4. Average leaching of potassium cation $\left(\mathrm{K}^{+}\right)$in $\mathrm{kg} \mathrm{ha}^{-1} \mathrm{yr}^{-1}$ in the years with different precipitation rate and discharge magnitude, 1995-2007

\begin{tabular}{ccccccc}
\hline Years & CON & INT & ORG1 & ORG2* & REF & LTP \\
\hline Normal & $1.64 \pm 0.67$ & $1.60 \pm 0.57$ & $1.48 \pm 0.39$ & $1.73 \pm 0.10$ & $1.30 \pm 0.62$ & $1.58 \pm 0.27$ \\
Dry & $0.68 \pm 0.40$ & $0.42 \pm 0.40$ & $0.52 \pm 0.44$ & $0.54 \pm 0.10$ & $0.83 \pm 0.59$ & $0.75 \pm 0.45$ \\
Wet & $5.43 \pm 1.74$ & $4.73 \pm 0.40$ & $3.69 \pm 0.50$ & $3.22 \pm 1.35$ & $3.16 \pm 0.21$ & $3.49 \pm 1.02$ \\
\hline
\end{tabular}

Explanations of treatments under Table 2; ORG2 - organic second; * - data for 1995-1999
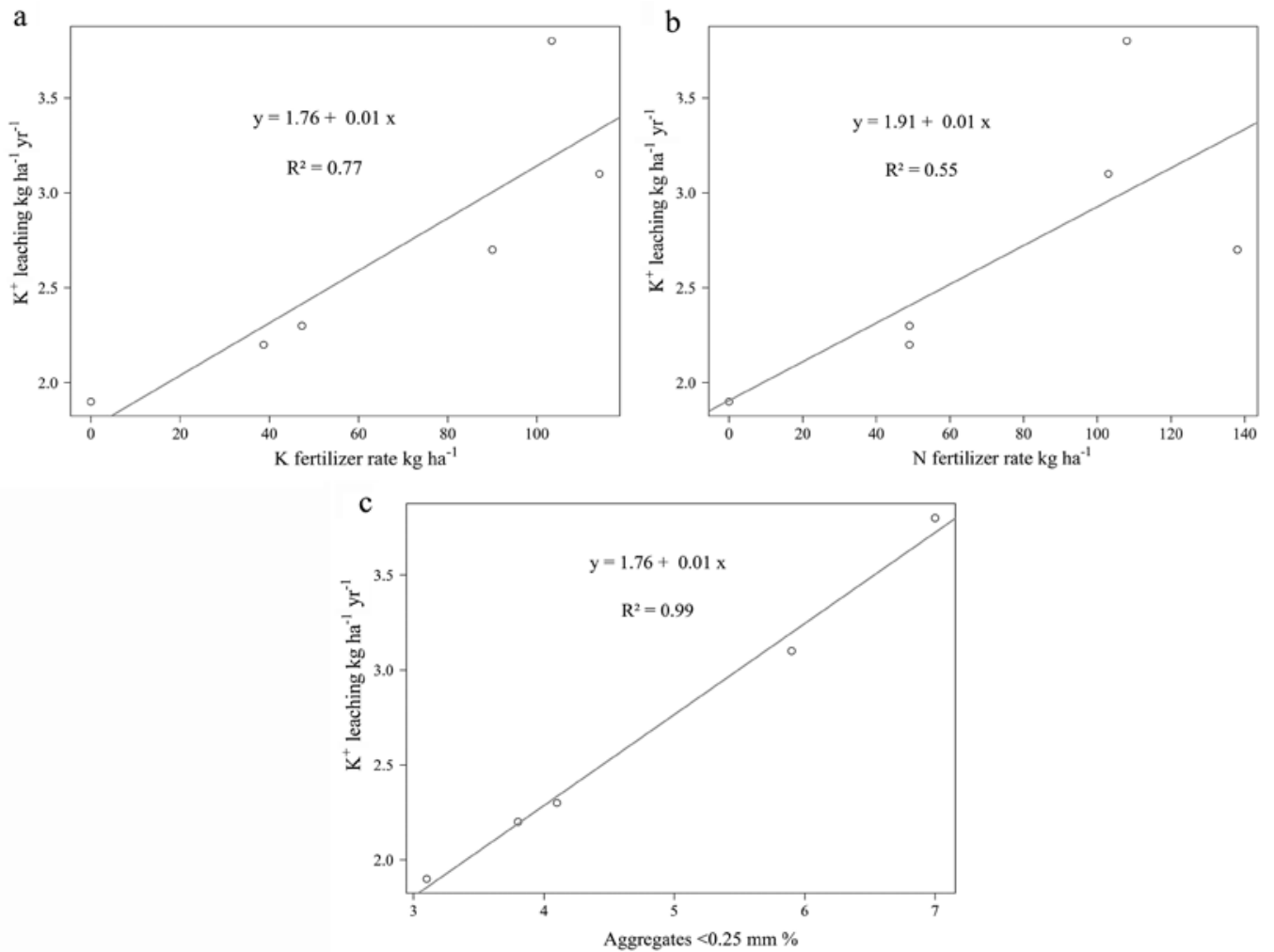

Figure 3. Relationships between potassium cation $\left(\mathrm{K}^{+}\right)$leaching and $\mathrm{K}$ fertilizer rate (a), $\mathrm{N}$ fertilizer rate $(\mathrm{b})$ and the content of soil aggregates $<0.25 \mathrm{~mm}$ (c), 1995-1999 
soil fraction $<0.25 \mathrm{~mm}$ in the topsoil during the first research period (Fig. $3 \mathrm{c}$ ).

Leaching of $\mathrm{K}^{+}(\mathrm{y})$ in $\mathrm{kg} \mathrm{ha}^{-1}$ year ${ }^{-1}$ increased linearly with increase of content of that fraction from $3 \%$ to $7 \%$ in the treatments with arable crops $(P<0.01)$ during the first research period. In this study, we found that the precipitation rate explained $64 \%$ of variance of the $\mathrm{K}^{+}$ leaching (Fig. 4 a). The final regression model explained $76 \%$ variance for all data and $65 \pm 16 \%$ on cross-validation data, showing relatively high and stable accuracy of predictions (Fig. $4 \mathrm{f}$ ). The precipitation rate was the most important factor from the main effects $(F=29 \pm 17)$, where $\mathrm{K}^{+}$leaching highly correlated with the factor at the precipitation rate more $500 \mathrm{~mm} \mathrm{yr}^{-1}$, whereas at the lower rate the correlation was low (Fig. 4 a). The importance of the content of humus and soil aggregates $<0.25 \mathrm{~mm}$ was low ( $F=4 \pm 3$ and $F=3 \pm 2$, respectively) compared with the precipitation rate. $\mathrm{K}^{+}$leaching slightly increased along with the content of humus and content of soil aggregates $<0.25 \mathrm{~mm}$ (Fig. $4 \mathrm{~b}, \mathrm{c}$ ). Two interactions were selected in the model: 1) precipitation rate and content of soil aggregates $<0.25 \mathrm{~mm}$ in the topsoil and 2) precipitation

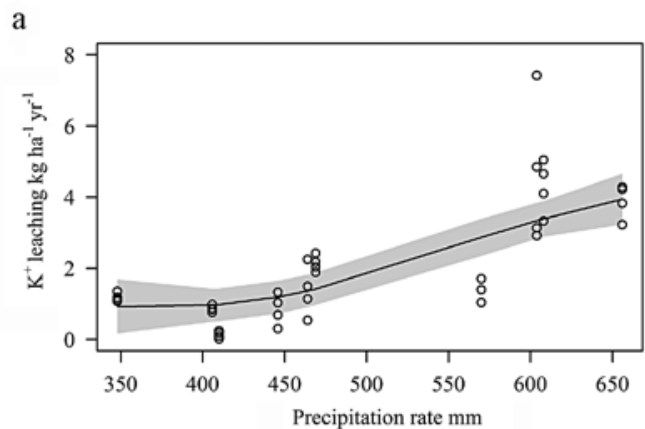

c

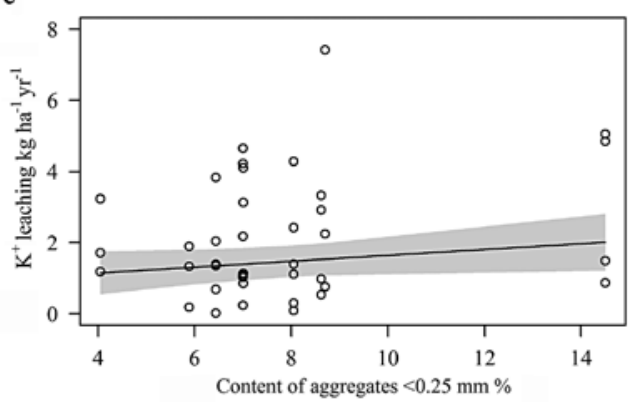

$\mathrm{e}$

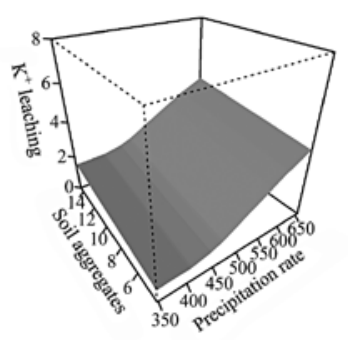

rate and content of humus in the topsoil (Fig. 4 d, e). Each alone interaction explained more than $60 \%$ of the variance of the $\mathrm{K}^{+}$leaching. In the cases, where precipitation was more $500 \mathrm{~mm}$ there was low correlation between the $\mathrm{K}^{+}$ leaching and the content of humus; however, no significant relationship was found between those parametres at precipitation rate $\leq 500 \mathrm{~mm}$. $\mathrm{K}^{+}$leaching correlated with soil aggregates $<0.25 \mathrm{~mm}$ at high and low precipitation rates. There were slightly stronger relationships between the $\mathrm{K}^{+}$leaching and precipitation rate at high values of content of humus and soil aggregates $<0.25 \mathrm{~mm}$ than at low values of both soil properties.

The climatic factor and particularly the precipitation rate, is one of the most important as shown in the majority of research papers related to the $\mathrm{K}$ and other nutrients leaching (Johnston et al., 2001; Gosling, Shepherd, 2005; Alfaro et al., 2006; Kolahchi, Jalali, 2006; Öborn et al., 2008; Singh, Goulding, 2008). The K concentration and amount in wet atmospheric deposits in experimental site during research period was fluctuating from year to year, and the average amount of deposited $\mathrm{K}$ was comparable to the results obtained in Graisupis

$\mathrm{b}$

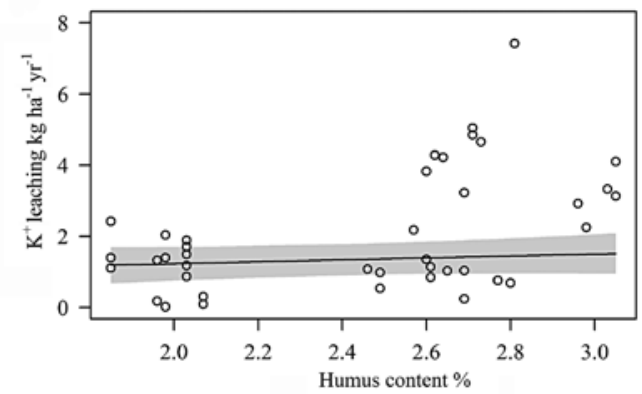

d

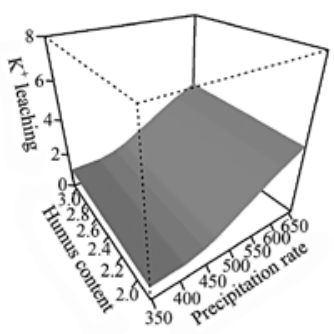

f

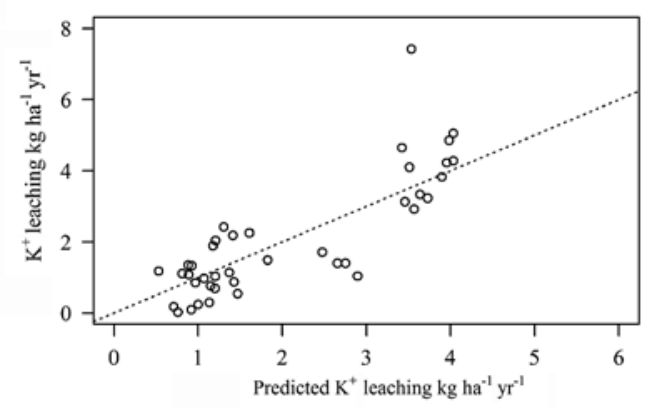

Note. Data based on 1995-2007.

Figure 4. Empirical relationships between potassium cation $\left(\mathrm{K}^{+}\right)$leaching and precipitation rate (a), content of humus in the topsoil (b), content of soil aggregates $<0.25 \mathrm{~mm}$ (c) and the interaction effect of precipitation with content of humus in the topsoil (d), content of soil aggregates $<0.25 \mathrm{~mm}$ in the topsoil (e) and the observed and predicted $\mathrm{K}^{+}$ leaching values using the non-linear model (f) 
river watershed (Bučienè, Gaigalis, 2012) and in other more distant places like southern and western Sweden (Eriksson, 2001). It is accepted that the extent to which soil $\mathrm{K}$ can be exploited will depend besides few factors, upon the cropping system (Askegaard, Eriksen, 2008). In the present research only the CON system influenced the significantly highest $\mathrm{K}^{+}$leaching losses with drainage runoff as compared with other treatments, and only in normal/wet years.

Leaching of $\mathrm{K}$ from grassland is usually low, but high levels of available soil $\mathrm{K}$ lead to increased $\mathrm{K}$ losses (Kayser, Isselstein, 2005). We determined no reliable difference in the $\mathrm{K}^{+}$leaching between the plots under the field crops and pasture, but in the drier years it was comparatively lower in pasture than in arable plots. On the other hand, the tendency of increased $\mathrm{K}$ concentration in drainage runoff with increase of plant available $\mathrm{K}_{2} \mathrm{O}-\mathrm{AL}$ content in the topsoil was determined, which agrees with other research results (Ulén, 1999; Kayser, Isselstein, 2005; Gužys, 2011). Fertilizers were least effective in the most strongly $\mathrm{K}$ fixing soil at Rothamsted and most effective in the soil with the highest cation exchange capacity at Bad Lauchstaedt (Germany), where the greater quantity of exchange sites appear to be associated with humic material (Blake et al., 1999). Also $\mathrm{N}$ fertilizer form, application rate and time influence soil $\mathrm{K}$ fixation and release, as well as $\mathrm{K}$ uptake, transport, cycling and reutilization within crops (Zhang et al., 2010). In this research we determined the positive impact of $\mathrm{K}$ and $\mathrm{N}$ fertilizers on $\mathrm{K}^{+}$leaching quantity, but only during the wet/normal years. We also observed the higher K plant uptake with perennial grasses in the LTP during both research periods; however, the decrease in $\mathrm{K}_{2} \mathrm{O}-\mathrm{AL}$ content till $40 \mathrm{~cm}$ depth was observed during the first research period only, and during the second it even increased sufficiently. Mikkelsen (2008) determined that deeprooted plants enhance soil mineral weathering by depleting rhizosphere $\mathrm{K}$ and causing a shift in the $\mathrm{K}$ equilibrium. That might be true for the LTP treatment with deeprooted perennial grasses in the sward.

High correlation was determined between the content of soil aggregates $<0.25 \mathrm{~mm}$ in topsoil and $\mathrm{K}^{+}$ leaching losses, that might be related to the higher content of $\mathrm{K}^{+}$in this fraction due to the weathering. That was also observed on a Calcaric Arenosol (ARc) and Haplic Arenosol $(A R h)$ in Lithuania (Galvydyte et al., 2007) and other humid regions of the former USSR (Соколова, 1985).

In our experiment, $\mathrm{K}^{+}$leaching increased with the higher precipitation rate and humus content in the topsoil: though the increase in humus content in general causes the higher adsorption of cations, including $\mathrm{K}^{+}$, probably the adsorbed part was relatively small as compared with that supposed to leach under higher discharge, caused by the increased precipitation rate. The changes in humus structural composition towards more fulvic acid compounds and thus lighter fraction might be benevolent for this process too (Liaudanskienè et al., 2011).

\section{Conclusions}

1. The differences between conventional $(\mathrm{CON})$ and reference (REF) treatments were statistically significant during the first research period with normal and/or wet hydrological years with an annual precipitation rate of more than $450-500 \mathrm{~mm}$. The potassium cation $\left(\mathrm{K}^{+}\right)$ leaching then was as follows: $\mathrm{CON}>\mathrm{INT}$ (integrated) $>$ LTP (long term pasture) $>$ ORG1 (organic first) $>$ REF.
During the next research period, which was running under the drier conditions, the leaching of $\mathrm{K}^{+}$was negligible and similar in all the treatments. The rate of $\mathrm{K}$ and $\mathrm{N}$ fertilizers and the content of soil aggregates $<0.25 \mathrm{~mm}$ in topsoil positively influenced the leaching of $\mathrm{K}^{+}$only during the normal and wet years.

2. More than $60 \%$ of the variation of $\mathrm{K}^{+}$ leaching was explained by the precipitation rate and by its interaction with content of humus and soil aggregates $<0.25 \mathrm{~mm}$ in topsoil.

\section{Acknowledgements}

The authors are grateful for the Grant received from the State Foundation of Science of Lithuania, which enabled the conduct of this research.

Received 17032013

Accepted 04112013

\section{References}

Agrochemical properties of Lithuanian soils and their change / compiled by J. Mažvila. 1998. Lithuanian Institute of Agriculture, p. 123-129 (in Lithuanian)

Alfaro M. A., Jarvis S. C., Gregory P. J. 2006. Factors affecting potassium leaching in different soils. Soil Use and Management. 20 (2): 182-189 http://dx.doi.org/10.1111/j.1475-2743.2004.tb00355.x

Askegaard M., Eriksen J. 2008. Residual effect and leaching of $\mathrm{N}$ and $\mathrm{K}$ in cropping systems with clover and ryegrass catch crops on a coarse sand. Agriculture, Ecosystems and Environment. 123 (1-3): 99-108 http://dx.doi.org/10.1016/j.agee.2007.05.008

Blake L., Mercik S., Koerschens M., Goulding K. W. T., Stempen S., Weigel A., Poulton P. R., Powlson D. S. 1999. Potassium content in soil, uptake in plants and the potassium balance in three European long-term experiments. Plant and Soil. $216(1-2): 1-14$ http://dx.doi.org/10.1023/A:1004730023746

Bučienè A., Gaigalis K. 2012. Chemical composition of wet deposits and drainage runoff in the agroecosystems: the case of Middle Lithuania. Baltica. 25 (2): 153-162 http://dx.doi.org/10.5200/baltica.2012.25.15

Bučienè A., Ślepetienè A., S̈imanskaitė D., Svirskienė A., Butkute B. 2003. Changes in soil properties under highand low-input cropping systems in Lithuania. Soil Use and Management. 19 (4): 291-297 http://dx.doi.org/10.1079/SUM2003209

Egnér H., Riehm H., Domingo W. R. 1960. Untersuchungen über die chemische Bodenanalyse als Grundlage für die Beurteilung des Nährstoffzustandes der Böden. II. Chemische Extractionsmethoden zur Phospor- und Kaliumbestimmung. Annals Royal Agricultural College, Sweden, 26: 199-215 (in German)

Eriksson J. 2001. Concentrations of 61 trace elements in sewage sludge, farmyard manure, mineral fertiliser, precipitation and in oil and crops. Swedish Environmental Protection Agency, report 5159. <http://mie.esab.upc. es/ms/informacio/miscellanea/Contaminants $\% 20 \mathrm{en} \% 20$ diferemts\%20productes.pdf $>$ [accessed 0402 2013]

Galvydytė D., Lukauskas E., Volungevičius J. 2007. Fliuvioglacialinių darinių dirvožemių dangos ypatumai. Geografija, 43 (1): 1-7 (in Lithuanian)

Gosling P., Shepherd M. 2005. Long-term changes in soil fertility in organic arable farming systems in England, with particular reference to phosphorus and potassium. Agriculture, Ecosystems and Environment, 105 (1-2): 425-432 http://dx.doi.org/10.1016/j.agee.2004.03.007

Gužys S. 2011. The influence of different soil use practices on mineral potassium leaching. Water Management Engineering Transactions, 38 (58): 5-13

Johnston A. E., Poulton P. R., Syers J. K. 2001. Phosphorus, potassium and sulphur cycles in agricultural soils. 
Proceedings No. 465. The International Fertiliser Society York, UK, 44 p.

Kayser M., Isselstein J. 2005. Potassium cycling and losses in grassland systems: a review. Grass and Forage Science, 60 (3): $213-224$

http://dx.doi.org/10.1111/j.1365-2494.2005.00478.x

Kolahchi Z., Jalali M. 2006. Simulating leaching of potassium in a sandy soil using simple and complex models. Agricultural Water Management. 85 (1-2): 85-94 http://dx.doi.org/10.1016/j.agwat.2006.03.011

Krauss A. 2000. Potassium, integral part for sustained soil fertility. Potassium and phosphorus: fertilisation effect on soil and crops: proceedings of the Regional IPI Workshop. Lithuanian Institute of Agriculture, p. 7-19

Liaudanskienè I., Šlepetienè A., Velykis A. 2011. Changes in soil humified carbon content as influenced by tillage and crop rotation. Zemdirbyste-Agriculture, 98 (3): 227-234

Mašauskas V., Mašauskienė A. 2006. Dynamics of potassium off-take and active potassium in soil. Vagos, 68 (21): 20-29

Mašauskas V., Mašauskienè A. 2010. Management of agroecosystem components. Results of long-term agrochemical experiments: a monograph / compiled by Tripolskaja L. et al. Lithuanian Research Centre of Agriculture and Forestry, p. 318-320 (in Lithuanian)

Mažvila J., Antanaitis A., Arbačiauskas J., Lubytė J., Adomaitis T., Mašauskas V., Vaišvila Z. 2004. Potassium tests using different methods and their suitability for Lithuanian soils. Zemdirbyste-Agriculture, 87 (3): 12-29 (in Lithuanian)

Mikkelsen R. 2008. Managing potassium for organic crop production. Better Crops, 92 (2): 26-29

Öborn I., Andrist-Rangel Y., Askegaard M., Grant C. A., Watson C. A., Edwards A. C. 2008. Critical aspects of potassium management in agricultural systems. Soil Use and Management. 21 (1): 102-112

http://dx.doi.org/10.1111/j.1475-2743.2005.tb00114.x
Singh B., Goulding K. W. T. 2008. Changes with time in the potassium content and phyllosilicates in the soil of the Broadbalk continuous wheat experiment at Rothamsted. European Journal of Soil Science, 48 (4): 651-659 http://dx.doi.org/10.1111/j.1365-2389.1997.tb00565.x

Tivy J. 1987. Nutrient cycling in agro-ecosystems. Applied Geography, 7: 93-113

http://dx.doi.org/10.1016/0143-6228(87)90044-0

Tyla A., Rimšelis J., Sleinys R. 1997. Leaching of nutrient matter of plants in different soils. Lithuanian Institute of Agriculture, 25 p. (in Lithuanian)

Ulén B. 1999. Leaching and balances of phosphorus and other nutrients in lysimeters after application of organic manures or fertilizers. Soil Use and Management, 15 (1): 56-61 http://dx.doi.org/10.1111/j.1475-2743.1999.tb00064.x

Vadiunina A., Korchiagina Z. 1986. Research methods of soil physical properties, Moscow, Russia, p. 62-72 (in Russian)

Wood S. N., Augustin N. H. 2002. GAMs with integrated model selection using penalized regression splines and applications to environmental modelling. Ecological Modelling. 157 (2-3): 157-177 http://dx.doi.org/10.1016/S0304-3800(02)00193-X

Zhang F., Niu J., Zhang W., Chen X., Li Ch., Yuan L., Xie J. 2010. Potassium nutrition of crops under varied regimes of nitrogen supply. Plant and Soil, 335 (1-1, spec. iss.). Cakmak I. (ed.). Potassium role and benefits in improving nutrient management for food production, quality and reduced environmental damages, p. 21-34

Zuur A. F., Ieno E. N., Smith G. M. 2007. Analysing cological data. New York, USA, $672 \mathrm{p}$.

Соколова Т. А. 1985. Глинистые минералы в почвах гумидных областей СССР. Новосибирск, Россия, 253 c. (in Russian)

ISSN 1392-3196 / e-ISSN 2335-8947

Zemdirbyste-Agriculture, vol. 101, No. 1 (2014), p. 3-10

DOI 10.13080/z-a.2014.101.001

\title{
Kalio išplova iš karbonatingo giliau glèjiško rudžemio, esant skirtingam kiekiui kritulių ir taikant ịvairias žemdirbystės sistemas
}

\author{
A. Bučienè ${ }^{1}, \breve{S}$. Antanaitis ${ }^{2}$, A. Šlepetienè ${ }^{2}$, D. Šimanskaité2 ${ }^{2}$ V. Mašauskas ${ }^{2}$, M. Bučas ${ }^{1}$ \\ ${ }^{1}$ Klaipèdos universitetas \\ ${ }^{2}$ Lietuvos agrarinių ir miškų mokslų centro Žemdirbystės institutas
}

\section{Santrauka}

Pirmuoju tyrimų laikotarpiu didžiausia kalio katijono $\left(\mathrm{K}^{+}\right)$išplova drenažo nuotekiu $\left(3,8 \mathrm{~kg} \mathrm{ha}^{-1}\right.$ per metus $)$ giliau karbonatingame giliau glejjiškame rudžemyje (RDg4-k2) nustatyta laukelyje, kuriame taikyta tradicinè žemdirbystès sistema ir gausiai tręšta mineralinèmis kalio trąšomis, o kontrolinio varianto išplova sieke tik $1,9 \mathrm{~kg} \mathrm{ha}^{-1}$ per metus. Tačiau antruoju tyrimų laikotarpiu, kurio metu vyravo sausringas klimatas, tyrimų schemoje padarius kelis pakeitimus, $\mathrm{K}^{+}$išplova drenažu visuose variantuose buvo nedidelè ir panašaus dydžio (maždaug $1,6 \mathrm{~kg} \mathrm{ha}^{-1}$ per metus). Kitos tyrimų metu taikytos žemdirbystės sistemos, pavyzdžiui, ekologinè arba integruota, taip pat ir ilgalaikè ganykla, $\mathrm{K}^{+}$išplovos dydžiui neturèjo reikšmingos įtakos.

$\mathrm{K}^{+}$išplova ariamoje žemejje tiesiogiai koreliavo su $\mathrm{K}$ bei $\mathrm{N}$ trąšų normomis ir dirvožemio $<0,25 \mathrm{~mm}$ dalelių kiekiu armenyje tik drègnais ir normalaus drègnumo metais. $\mathrm{K}^{+}$išplova labiausiai priklausè nuo metų drègnio, t. y. iškritusių kritulių kiekio (64 \%). Gautas netiesinis regresinis modelis paaiškina $76 \% \mathrm{~K}^{+}$išplovos variacijos su visais duomenimis ir $65 \pm 16 \%$ su patikros duomenimis, tai rodo sąlygiškai gerą ir stabilu prognozavimo tikslumą. Tarp tikrintų veiksnių ịtakos nustatytos dvi reikšmingos (paaiškinančios daugiau nei $60 \% \mathrm{~K}^{+}$išplovos variacijos) sąveikos: 1) tarp kritulių ir humuso kiekio armenyje ir 2) tarp kritulių bei dirvožemio $<0,25 \mathrm{~mm}$ dalelių kiekio. Kiti tirti veiksniai, pavyzdžiui, mineralinių $\mathrm{K}$ ir $\mathrm{N}$ trąšų normos, judriojo $\mathrm{K}_{2} \mathrm{O}$ kiekis dirvožemyje, nebuvo tokie reikšmingi prognozuojant $\mathrm{K}^{+}$išplovą, todèl ị galutinị modelị neįtraukti.

Reikšminiai žodžiai: humuso kiekis, išplova, kalio katijonas $\left(\mathrm{K}^{+}\right)$, krituliai, žemdirbystès sistemos. 